\title{
Capital structure of Portuguese hotel firms: a structural equation modelling approach
}

\section{Estrutura do capital das empresas hoteleiras portuguesas: aplicação do modelo de equações estruturais}

\author{
Fernanda Matias \\ University of Algarve, School of Management, Hospitality and Tourism, Campus da Penha, 8005-139 Faro, Portugal, \\ mfmatias@ualg.pt
}

\section{Leonor Salsa}

University of Algarve, School of Management, Hospitality and Tourism, Campus da Penha, 8005-139 Faro, Portugal, mlsalsa@ualg.pt

\section{Carlos Miguel Afonso}

University of Algarve, School of Management, Hospitality and Tourism, Campus da Penha, 8005-139 Faro, Portugal, cafonso@ualg.pt

\begin{abstract}
This paper addresses capital structure determinants for Portuguese hotel firms between 2006 and 2014. Secondary data from 356 hotel units was analysed using the partial least squares (PLS) statistical technique, a variance-based structural equation modelling (SEM). The results show that the explanatory variables proposed as capital structure determinants have an impact on the financing and debt decisions made by the firms in the sample. Of these, tangibility has the greater explanatory power. Overall, the results support the notion that trade-off theory and pecking-order theory are important in explaining the capital structure of the Portuguese hotel industry, particularly as regards the agency conflicts triggered by growth opportunities and the preference firms have for internal funding. The results also point to the importance of collateral in accessing credit and the lesser impact of asymmetric information pertaining to tangible asset value and firm size. The results suggest small firms find it difficult to contract loans, which can somewhat limit their growth and performance.
\end{abstract}

Keywords: Capital structure, hospitality, structural equation modelling, debt, management.

\section{Resumo}

Este trabalho investiga os determinantes da estrutura de capital de empresas hoteleiras em Portugal no período de 2006-2014. Os dados secundários referentes a 356 unidades hoteleiras foram analisados com recurso à técnica estatística de mínimos quadrados parciais e respetivo modelo de equações estruturais, baseado na variância. Os resultados obtidos evidenciam que as variáveis explicativas propostas como determinantes da estrutura de capital têm impacto nas decisões sobre o endividamento das empresas da amostra, sendo a tangibilidade a que tem maior poder explicativo. No geral, os resultados apresentados sustentam que as teorias do trade-off e da pecking-order não são mutuamente exclusivas e são importantes na explicação da estrutura de capital das empresas hoteleiras portuguesas, nomeadamente quanto aos conflitos de agência suscitados pelas oportunidades de crescimento e à preferência das empresas pelo financiamento por fundos internos. Os resultados apontam também para a relevância no acesso ao crédito da característica de colateralidade e menor severidade da informação assimétrica associada ao valor dos ativos tangíveis e à dimensão da empresa. Neste contexto, os resultados sugerem a existência de dificuldades das pequenas empresas na contração de empréstimos e, eventualmente, o condicionamento do seu crescimento e desempenho.

Palavras-chave: Estrutura de capital, indústria hoteleira, modelo de equações estruturais, dívida empresarial, gestão.

\section{Introduction}

The capital structure of a firm reflects the various business decisions taken by managers that have an impact on the firm's economic, financial and social performance. As a result, capital structure determinants have been one of the most intensively researched topics in the context of corporate finance, particularly since Modigliani and Miller (1958, 1963). Their work, which was based on simplifying business and financial assumptions, led to the construction of a solid theoretical framework for such determinants.

A wide range of empirical studies have looked at a number of financial (and non-financial) characteristics of firms as potential determinants of corporate debt level. In recent years, these have focused on studying behaviour with respect to such theories as trade-off and pecking-order. Empirical research has fallen in comparison between countries (Rajan \& Zingales, 1995; Hall, Hutchinson \& Michaelas, 2004; Mateev, Poutziouris \& Ivanov, 2013), in a specific country (Michaelas, Chittenden \&
Poutziouris, 1999. Lopez-Gracia \& Sogorb-Mira, 2008; Serrasqueiro \& Caetano, 2015) or in a specific activity (for example in the hospitality sector, Matias \& Baptista, 1998; Dalbor \& Upneja, 2004; Tang \& Jang, 2007; Devesa \& Esteban, 2011 and Serrasqueiro \& Nunes, 2014).

Empirical research of capital structure is dominated by multiple linear regression models with proxies for unobservable theoretical determinants. As Titman and Wessels (1988) report, this methodology presents some problems, including the fact that there is often more than one possible proxy and that these proxies can measure the effects of different determinants and can constitute imperfect representations of the constructs to be measured. Conventional regression analysis does not control the measurement errors and cannot simultaneously adjust the models of various dependent variables. Indeed, the financial capital structure determinants can be compared to constructs measured by a number of indicators or proxies, without causing the multicollinearity problems frequently encountered in 
financial studies. Titman and Wessels (1988), Chiarella, Pham, Sim and Tan (1991) Jairo (2008), Chang, Lee and Lee (2009) and Chen and Chen (2011) applied structural equation modelling (Structural Equation Modelling, henceforth SEM) to the study of the capital structure determinants. SEM mitigates the limitations of traditional regression equations.

The main goal of this study is to investigate the financial capital structure determinants and the evidence for the applicability of trade-off and pecking-order theories to firms in the hotel sector in Portugal, by applying SEM. This sector is of scientific interest because it evidences a set of characteristics, such as fixed capital intensity, that can facilitate access to credit (collateral value). However, access to credit can also be complicated because of fixed costs, which usually increase business risk. Another key characteristic is seasonality. The results are discussed in relation to capital structure theories, particularly trade-off and pecking-order. The study sampled 356 firms between 2006 and 2014.

This study will enrich empirical research in three ways. Firstly, it will deepen our understanding of the financing of the Portuguese hotel industry, which, although an essential component of the tourism industry has not yet been subjected to intense study. The sector has a major impact on the Portuguese economy and, according to the World Travel \& Tourism Council (2016), accounted for $6.1 \%$ and $6.4 \%$ of GDP in 2014 and 2015 (compared to 3.5\% in Europe and 3.0\% in the rest of the world, on average in 2015). The sector has contributed significantly over the years, through $8 \%$ of direct employment, $20 \%$ of total employment (including indirect and induced) and $20 \%$ of national exports. Accommodation is a key contributor in terms of tourism development. In 2014 (INE, $2015)$, the hotel sector accounted for $86.5 \%$ of all guests and $89.2 \%$ of all overnight stays.

Secondly, our study makes use of PLS-SEM, a variance-based statistical technique that has not yet been used in applied research into the capital structure determinants in Portugal. Thirdly, it allows for the comparison of the empirical results obtained in this study with those from two groups of capital structure studies that used the same methodology and applied it to the hotel industry.

The results show that the explanatory variables proposed as capital structure determinants have an impact on decisions about the indebtedness of firms in the sample and that, of these, tangibility has the greatest explanatory power. Overall, the results indicate that the trade-off and pecking-order theories are not mutually exclusive and that the two are important in explaining the capital structure of the Portuguese hotel industry. More specifically, they suggest that agency conflicts arise from growth opportunities and a preference for internal funding. The results also highlight the importance of collateral value in accessing credit and the lesser impact of asymmetric information associated with tangible asset value and firm size. In this context, the results suggest that small businesses find it difficult to contract loans and their growth and performance may be affected by this.

Section 2 of this paper comprises a brief review of the relevant theoretical and empirical research and the hypotheses being tested. Section 3 addresses the methodology used. The results are presented in section 4. Finally, section 5 offers our conclusions.

\section{Literature review and research hypothesis}

Titman and Wessels (1988) first applied SEM to capital structure research, using a sample of 469 US firms between 1974 and 1982. They estimated parameters with eight latent constructs measured by 21 indicators and six debt ratios. Although the results proved statistically insignificant, this study led to further work on capital structure that made use of the same research technique. The indicators studied were: collateral value of assets, non-debt tax shields, volatility of results (risk), future growth, specificity of the assets, activity sector, size and profitability (the first four of these determinants are not statistically significant). The authors suggest that the weak consistency of the results is possibly accounted for by the fact that the indicators do not adequately reflect the nature of the attributes suggested by the financial literature.

Chiarella et al. (1991) used the SEM to study capital structure and its determinants in the context of 226 Australian firms. The results were not statistically significant with regards to growth opportunities, collateral value of assets or cash holdings but do show negative relationships with profitability and non-debt tax shields to debt and a positive one with size and debt level.

Jairo (2008) investigated the capital structures of 651 British firms, also using the SEM. The results, which are consistent with the dominant financial theories, led the author to conclude that variables like non-debt tax shields, risk and probability of bankruptcy are negatively correlated to debt, while tangibility, size and profitability (current) have a positive relationship.

On the basis of Titman and Wessels (1988), Chang et al. (2009) presented a SEM-MIMIC (SEM-Multiple Indicators and Multiple Causes) for capital structure determinants that had three debt indicators and several independent variables that were statistically significant. Their results showed that growth is the most important variable in explaining capital structure, and that profitability, collateral value, volatility of results, non-debt tax shields and uniqueness are also significant, in the same descending order of explanatory power.

Chen and Chen (2011) also studied capital structure determinants and their impact on firm value. They looked for empirical evidence in listed enterprises in Taiwan between 2005 and 2009, using a SEM. The results showed that size, profitability and tangibility level of assets are explanatory variables of total debt, but growth opportunities are not.

The hospitality sector has specific characteristics that can determine how firms are financed and their resulting capital 
structure. These include fixed capital intensity, seasonality and hotel category. As this information is not available in the commonly used databases, many studies use financial determinants only. Most of the studies mentioned in the introduction focused on financial determinants, as did our research. Of these studies, two are based the United States (Dalbor \& Upneja, 2004; Tang \& Jang, 2007), one on Spain (Devesa \& Esteban, 2011) and two on Portugal (Matias \& Baptista, 1998; Serrasqueiro \& Nunes, 2014).

Matias and Batista (1998) used data from 21 Algarve hospitality businesses provided by the Bank of Portugal. They concluded that the most profitable firms tend to borrow less and firms with higher collateral value also have lower debt ratios.

Dalbor and Upneja (2004) looked at the 1981-2000 data for 171 American hotel firms. Their results suggest a positive relationship between tangibility, risk and growth opportunities with regard to medium and long-term debt. They found an unexpected positive relationship between long-term debt and growth opportunities and claim that this may be explained by the fact that the type of investments made by hotels is more easily financed by long-term loans (real estate investment). Short-term loans are best suited to controlling agency problems.

Tang and Jang (2007) compared the capital structure determinants of hotel firms with software firms. The study focused on 1997-2003 data from 12 hotel firms and 10 software firms. Their results indicate that hotels have a positive and statistically significant relationship with fixed assets, growth opportunities and the variable for the interaction between fixed assets and growth opportunities. All the other variables, including earnings volatility, size, agency costs and profitability are not statistically significant.

Devesa and Esteban (2011) investigated total debt using 20002003 business data from the Spanish hotel industry. They consolidated their independent variables factors as follows: current ratio, liquidity ratio and cash-flow ratio as factor 1 ; tangibility, collateral and other assets as factor 2; assets and sales as factor 3 ; variation in sales and variation in assets as factor 4 and finally the return on assets as factor 5 . Their results show that factor 1 explains $19 \%$ of total debt, factor 2 explains $15 \%$, factors 3 and 4 explain $10 \%$ and factor 5 explains just $6 \%$. Nevertheless, factors 1 and 2 show a mostly negative relationship with total debt and factor 5 has a negative relationship with annual debt. Factors 3 and 4 show a predominantly positive relationship with debt.

Serrasqueiro and Nunes (2014) conclude that trade-off and pecking-order theories are not mutually exclusive in their explanation of the indebtedness of small and medium-sized Portuguese hotel businesses (SME) and that both make a significant contribution to this explanation. The study sample follows the hierarchy of funding proposed by pecking-order theory. The trade-off theory is relevant in explaining corporate capital structure decisions at Portuguese hotel SME. Size and tangibility show a positive relationship with debt and growth opportunities and non-debt tax shields and risk a negative relationship with indebtedness.

This paper aims to investigate various corporate financial characteristics that have been presented as capital structure determinants in previous studies, such as growth opportunities, size, age, non-debt tax shields, profitability (past) and tangibility.

\section{Growth opportunities}

Firms with higher growth opportunities are most in need of funding and, according to pecking-order theory, will have higher indebtedness. Given the hierarchy of funding sources proposed by Myers (1984), firms prefer to use debt to increase equity, when internal funds are exhausted. Harris and Raviv (1991), for example, point to a positive relationship between growth opportunities and the level of corporate indebtedness.

However, according to trade-off theory, growth opportunities have a negative relationship with the level of corporate indebtedness, because firms with greater investment opportunities face increased agency costs, higher bankruptcy costs, more difficulties in obtaining external credit and therefore lower indebtedness.

Studies similar to those of Dalbor and Upneja (2004) and Tang and Jang (2007) have observed a positive relationship between growth (assets) and debt. However, Lopez-Gracia and SogorbMira (2008) and Serrasqueiro and Nunes (2014), for example, found a negative correlation between those variables. Since the evidence is contradictory, and given the specificity of the hotel business, it is likely that firms are bewary of the risk of defaulting associated with financing investment opportunities through debt. This underpins the following hypothesis:

Hypothesis 1: Growth opportunities have a negative influence on debt.

\section{Size}

According to trade-off theory, size has a positive relationship with debt, on the basis that larger firms have more debt capacity, can meet creditor commitments and have lower bankruptcy costs. According to Scott (1976), larger firms with higher asset values provide the best debt guarantees. Also Ang (1992), Rajan and Zingales (1995) and Cole (2013) find that larger firms are more diversified, have lower bankruptcy costs and, as such, represent a lower risk for lenders. Devesa and Esteban (2011) put forward a similar argument in their study of the hospitality industry.

According to Myers and Majluf (1984), the information asymmetry will be lower in larger firms, which could facilitate the use of debt. Pecking-order theory stipulates that debt and firm size correlate positively, although the original theory does not refer to size as a capital structure determinant. 
The results obtained by Harris and Raviv (1991), Chen and Chen (2011) and Serrasqueiro and Nunes (2014) support the following hypothesis:

Hypothesis 2: Firm size has a positive influence on debt.

\section{Age}

According to trade-off theory, firm longevity tends to be reflected in credibility, profitability and diversification. Firms that have been in business longer tend to be more credible, profitable and diversified than newer ones, so they will be less like to suffer financial distress (Cole, 2013). Studies such as Michaelas et al. (1999), Lopez-Gracia and Sogorb-Mira (2008) and Serrasqueiro and Caetano (2015) investigate this capital structure determinant as an explanatory variable of debt and conclude that it has explanatory power and a negative and statistically significant relationship with debt.

Hypothesis 3: Firm age has a negative influence on debt.

\section{Non-debt tax shields}

The trade-off theory suggests a negative relationship between non-debt tax shields and debt, based on the tax advantage that managers look for when using debt. Thus, the tax savings associated such values as fixed asset depreciation and amortization may replace the tax savings achieved through debt (DeAngelo \& Masulis, 1980). Firms with greater non-debt tax shields tend to include less debt in their capital structure. The empirical results are not consensual. Titman and Wessels (1988) did not obtain significant results and Chang et al. (2009) find a positive relationship (when using the ratio of depreciation and amortization for the period divided by total assets). However, Jairo (2008), Lopez-Gracia and Sogorb-Mira (2008) and Serrasqueiro and Nunes (2014) find a negative relationship. Nevertheless, and considering that the hotel industry is capitalintensive, it is possible that non-payable costs associated with the depreciation of tangible assets are relevant in terms of tax benefits and therefore the following hypothesis is formulated:

Hypothesis 4: Non-debt tax shields has a negative influence on debt.

\section{Profitability}

According to trade-off theory, past profitability correlates positively with debt, because the more profitable firms are, the more able to borrow and fulfil the financial obligations associated with debt, by taking advantage of the tax benefits, and they have lower bankruptcy costs. Moreover, debt plays a disciplinary role in the relationships between managers and equity holders, thus helping to reduce the agency costs between these stakeholders.

However, pecking-order theory specifies that profitability and debt are negatively correlated. Myers (1984) concludes that there is a funding source hierarchy and points out that firms prefer to use internal funds to finance new projects and they only use debt when such funds prove insufficient (equity is used as a last resort).

The results obtained by Titman and Wessels (1988), Chiarella et al. (1992), Matias and Baptista (1998), Devesa and Esteban (2011) and Serrasqueiro and Caetano (2015) show a negative relationship between profitability and debt, but Tang and Jang (2007) find no statistically significant relationship between them.

Hypothesis 5: Profitability has a negative influence on debt.

\section{Tangibility}

Several studies based on trade-off and pecking-order theories assume that the type of assets held by firms affects their choices about capital structure. This is so because tangible assets can be used as collateral in the event of bankruptcy and firms with higher collateral value tend to issue more debt and/or have higher indebtedness, especially in the medium and long term (Scott, 1976; Myers \& Majluf, 1984). Harris and Raviv (1991) argue that firms with more valuable tangible assets have a higher settlement value and greater debt capacity.

According to Chiarella et al. (1991), the cost of debt for firms without collateral may become too high, as tangible assets serve as security. Chen and Chen (2011) argue that tangible assets have a positive relationship with debt while intangibles show a negative relationship.

Tang and Jang (2007) identify a positive relationship between tangibility and debt in the hospitality sector, just as Jairo (2008), Chang et al. (2009) and Serrasqueiro and Caetano (2015) found in other sectors. Given the above, the following hypothesis is formulated:

Hypothesis 6: Tangible assets have a positive influence on total debt.

\section{Methodology}

This study takes a positivist and quantitative approach. First, we carried out a review of the literature on financial capital structure determinants and identified a number of variables worth investigating, as well as the hypotheses to be tested. The literature review process was conducted in accordance with the recommendations made by Webster and Watson (2002).

We then collected secondary data from the Amadeus database, provided by Bureau van Dijk, and prepared this using Microsoft Excel. The study is based on the 2006-2014 financial data from a final sample of 356 Portuguese hotel industry companies.

The sample size was analysed by power. As can be seen, we had significantly more than the 97 records necessary for an average size effect, with a power of $0.80, \alpha=0.05$ and six predictors (Green, 1991). Data was subjected to prior validation, to avoid errors in the calculations of the variables under study. Firms in the following situations were removed from the sample: fixed assets exceed total assets; equity with a negative value; no information available for all variables in all years. 
Data analysis, designed to characterise the data, was performed on using descriptive statistics (Gefen, Straub \& Rigdon, 2011). To investigate the variables related to the level of indebtedness and test our hypotheses, we used a variance-based structural equation modelling (SEM) statistical technique, called the partial least squares (PLS) technique (Roldán \& Sánchez-Franco, 2012). This technique allows us to adjust the models without the variables necessarily having normal distributions (Henseler, Ringle \& Sinkovics, 2009). We used the SmartPLS programme version 3.0 (Ringle, Wende \& Becker, 2015) for the purpose.

In line with other authors, such as Titman and Wessels (1988), the sample period was divided into three sub-periods of three years each, the average for each of these sub periods having been calculated. This calculation reduces measurement errors due to annual random fluctuations in the values of variables
(Titman \& Wessels, 1988). Latent dependent variables were measured for 2009-2011. The two growth opportunity indicators were measured for 2012-2014, which allowed us to use these values as imperfect approximations of the expected values at the time of a firm's funding decisions (Titman \& Wessels, 1988). A similar period of time was applied to the measurement of tangibility and non-debt tax shields. Size and profitability indicators were also obtained for 2006-2008. Measuring size in the initial sub-period avoids the possible creation of a false relationship between this variable and debt ratios (Titman \& Wessels, 1988).

To test the effect of the capital structure determinants and apply the PLS technique, we adopted proxies that have been used in the other empirical studies cited. Table 1 lists the constructs to be investigated and the respective indicators and measures.

Table 1 - Constructs and Indicators

\begin{tabular}{|c|c|c|c|}
\hline Constructs & Period & Indicators & Measures \\
\hline \multicolumn{4}{|l|}{ Dependents: } \\
\hline Total debt (LEV) & 2009-2011 & LEV & Ratio between Debt and Total Assets \\
\hline Long term debt (LLEV) & 2009-2011 & LLEV & Ratio between Long-term Debt and Total Assets \\
\hline \multicolumn{4}{|l|}{ Independents: } \\
\hline \multirow{2}{*}{$\begin{array}{l}\text { Growth opportunities } \\
\text { (GO) }\end{array}$} & \multirow[t]{2}{*}{$2012-2014$} & GOA & Ratio between (Total Assetst-Total Assett-1) and Total Assetst-1 \\
\hline & & GOT & Ratio between (Turnovert-Turnover ${ }_{t-1}$ ) and Turnover ${ }_{t-1}$ \\
\hline \multirow[t]{2}{*}{ Size (SIZE) } & \multirow[t]{2}{*}{ 2006-2008 } & SIZEA & Natural logarithm of Total Assets \\
\hline & & SIZET & Natural logarithm of Turnover \\
\hline Age (AGE) & 2006 & AGE & Natural logarithm of Age \\
\hline \multirow{2}{*}{$\begin{array}{l}\text { Non-debt tax shields } \\
\text { (NDTS) }\end{array}$} & \multirow[t]{2}{*}{$2009-2011$} & NDTS & Ratio between Depreciations and Amortizations and Total Assets \\
\hline & & NDTSR & Ratio between Depreciations and Amortizations and EBITDA \\
\hline \multirow[t]{2}{*}{ Profitability (PROF) } & \multirow[t]{2}{*}{$2006-2008$} & PROFA & Ratio between EBIT and Total Assets \\
\hline & & PROFT & Ratio between EBIT and Turnover \\
\hline \multirow[t]{2}{*}{ Tangibility (TANG) } & \multirow[t]{2}{*}{ 2009-2011 } & TANG & Ratio between Tangible Assets and Total Assets \\
\hline & & TANGA & Ratio between (Inventories + Tangible Assets) and Total Assets \\
\hline
\end{tabular}

Legend: EBIT - Earnings before interest and taxes / EBITDA - Earnings before interest, taxes, depreciation, and amortization Source: Authors.

According to Tang and Jang (2007), hotel firms typically use a high percentage of long-term debt to finance fixed assets, so medium and long-term debt may provide more specific information about financial decisions than the short-term debt. Given this, we decided to measure the capital structure through two dependent variables: total debt ratio and medium and long-term debt ratio. All the indicators were calculated using their book values, the only ones available on the target firms. Graham and Harvey (2001) have pointed out that managers use book values when making decisions about the capital structure of their business.

\section{Results}

\subsection{Descriptive statistics}

The descriptive statistics for the latent variable indicators are listed in Table 2. The Portuguese hotel firms in the sample, which are, on average, 58 years old, finance roughly half of their applications using debt. This is distributed almost equally between short and medium and long terms. The average value of their assets is approximately 1,505.2 thousand euros and their average turnover is 458.5 thousand euros. Their tangible assets

represent $60 \%$ of total assets, on average. In the period under consideration, total assets grew an average of $8.6 \%$, while turnover grew slightly faster, by $12.6 \%$. Depreciations and amortizations for the period reached $5.5 \%$ of total assets and average asset profitability is positive $(1.8 \%)$, while turnover profitability is negative $(-4.7 \%)$

\begin{tabular}{|l|c|c|c|c|}
\hline \multicolumn{5}{|c|}{ Table 2 - Descriptive Statistics 2006-2014 } \\
\hline Indicators & Observations & Mean & $\begin{array}{c}\text { Standard } \\
\text { deviation }\end{array}$ & Median \\
\hline LEV & 3204 & 0.5018 & 0.2589 & 0.5278 \\
\hline & & & & \\
\hline LLEV & 3204 & 0.2495 & 0.2498 & 0.1912 \\
\hline GOA & 3204 & 0.0865 & 0.1958 & -0.0166 \\
\hline GOT & 3204 & 0.1263 & 1.2161 & 0.0114 \\
\hline SIZEA & 3204 & 7.3073 & 1.8858 & 7.3251 \\
\hline SIZET & 2848 & 6.1152 & 1.7725 & 6.1322 \\
\hline AGE & 3204 & 58.6500 & 46.3000 & 34.0000 \\
\hline NDTS & 3204 & 0.0545 & 0.0373 & 0.0469 \\
\hline NDTSR & 3204 & -0.0843 & 41.4810 & 0.6153 \\
\hline PROFA & 3204 & 0.0183 & 0.0863 & 0.0146 \\
\hline PROFT & 3204 & -0.0466 & 0.9937 & 0.0428 \\
\hline TANG & 3204 & 0.6022 & 0.2967 & 0.6779 \\
\hline TANGA & 3204 & 0.6454 & 0.2821 & 0.7243 \\
\hline
\end{tabular}




\subsection{Measurement and structural models}

The PLS, a second-generation multivariate statistical technique, permits the simultaneous estimation of the measurement model, which shows the relationship between each latent variable and the observed indicators, and the structural model, which features the relationships between latent variables (Gefen \& Straub, 2005) as shown in table 3.

In this study we applied the reflective method to the measurement model. As noted below, the model was analysed for individual indicator reliability and was also subject to a reliable, convergent and divergent analysis, through observation for each latent variable loading, average variance extracted (AVE) and composite reliability (CR) (Gefen et al., 2011).

Table 3 shows the loadings and cross-loadings of the measurement model. Most of the indicator loadings, with the exception of GOT and PROFT, exceed the acceptable reliability limit of 0.7. However, we decided to keep the GOT and PROFT indicators, since their values are not less than 0.5 and are higher than the minimum required level of 0.4. Moreover, the respective constructs have acceptable values, that is, CR is over 0.7, AVE is over 0.5 and discriminant validity may also contribute to content validity (Roldán \& Sánchez-Franco, 2012).

Table 3 - Measurement Model: Loadings and Cross-loadings

\begin{tabular}{|c|c|c|c|c|c|c|c|c|}
\hline Indicators & Total debt & $\begin{array}{l}\text { Long term } \\
\text { debt }\end{array}$ & $\begin{array}{c}\text { Growth } \\
\text { opportunities }\end{array}$ & Size & Age & $\begin{array}{l}\text { Non-debt } \\
\text { tax } \\
\text { shields }\end{array}$ & Profitability & Tangibility \\
\hline LEV & 1.0000 & 0.6990 & -0.1428 & 0.1371 & -0.1678 & -0.0913 & -0.1779 & 0.2079 \\
\hline LLEV & 0.6990 & 1.0000 & -0.1479 & 0.1615 & -0.1312 & -0.0857 & -0.0865 & 0.1899 \\
\hline GOA & -0.1176 & -0.1424 & 0.8663 & -0.0657 & -0.0243 & 0.0641 & 0.0850 & -0.1343 \\
\hline GOT & -0.0971 & -0.0679 & 0.6118 & -0.0171 & 0.0549 & -0.0801 & -0.0315 & -0.0338 \\
\hline SIZEA & 0.1532 & 0.1908 & -0.0690 & 0.9835 & -0.0421 & -0.1930 & -0.1332 & 0.1935 \\
\hline SIZET & 0.0958 & 0.0937 & -0.0413 & 0.9434 & -0.0266 & -0.1180 & 0.1387 & -0.0066 \\
\hline AGE & -0.1678 & -0.1312 & 0.0082 & -0.0378 & 1.0000 & -0.0096 & 0.0547 & -0.1441 \\
\hline NDTS & -0.0734 & -0.0673 & 0.0441 & -0.2853 & -0.0184 & 0.7858 & 0.0174 & 0.2233 \\
\hline NDTSR & -0.0614 & -0.0595 & -0.0340 & 0.0559 & 0.0059 & 0.6936 & -0.0510 & -0.0055 \\
\hline PROFA & -0.1795 & -0.0885 & 0.0510 & -0.0442 & 0.0545 & -0.0164 & 0.9997 & -0.3155 \\
\hline PROFT & -0.0233 & 0.0361 & 0.0651 & 0.2053 & 0.0366 & -0.1156 & 0.5016 & -0.1978 \\
\hline TANG & 0.1516 & 0.1782 & -0.1213 & 0.1145 & -0.1220 & 0.1966 & -0.3080 & 0.9586 \\
\hline TANGA & 0.2394 & 0.1883 & -0.1196 & 0.1291 & -0.1529 & 0.1189 & -0.3056 & 0.9760 \\
\hline
\end{tabular}

Note: Indicators and constructs are defined in table 1. Source: Authors.

The values for the $C R$ of constructs, detailed in table 4, allow us to conclude these are all reliable because they exceed the limit of 0.7 suggested by Henseler, Ringle and Sarstedt (2012), as a reference for an appropriate model. Furthermore, there are
AVE values in the same table that allow us to assess convergent validity, according to which the set of indicators represents one and the same construct. These values exceed the threshold of 0.5 stipulated by Henseler et al. (2009), so we infer the convergent validity of the model.

Table 4 - Composite Reliability and Convergent Validity

\begin{tabular}{|l|c|c|}
\hline \multicolumn{1}{|c|}{ Constructs } & $\begin{array}{c}\text { Composite } \\
\text { reliability (CR) }\end{array}$ & $\begin{array}{c}\text { Average variance } \\
\text { extracted (AVE) }\end{array}$ \\
\hline Total debt & 1.0000 & 1.0000 \\
\hline Long term debt & 1.0000 & 1.0000 \\
\hline Growth opportunities & 0.7140 & 0.5624 \\
\hline Size & 0.9630 & 0.9286 \\
\hline Age & 1.0000 & 1.0000 \\
\hline Non-debt tax shields & 0.7083 & 0.5493 \\
\hline Profitability & 0.7506 & 0.6255 \\
\hline Tangibility & 0.9668 & 0.9357 \\
\hline \multicolumn{2}{|c|}{ Note: Constructs are defined in table 1. } \\
Source: Authors. \\
\hline
\end{tabular}

We analysed discriminant validity, the extent to which one construct differs from another, using the Fornell-Larcker criterion (Fornell \& Cha, 1994). The comparison of the square roots of AVE, in bold in Table 5, with the other values in the table shows there is discriminant validity for all constructs.
Moreover, the loadings and cross-loadings in Table 3 reveal that the loadings of each indicator are higher in the construct they are designed to measure and that each construct has higher loadings on the indicators proposed in the model, thus strengthening the evidence for discriminant validity (Roldán \& Sánchez-Franco, 2012). 
Table 5- Analysis of Discriminant Validity - Fornell-Larcker Criterion

\begin{tabular}{|l|l|l|l|l|l|l|l|l|}
\hline \multicolumn{1}{|c|}{ Constructs } & $\begin{array}{c}\text { Total } \\
\text { debt }\end{array}$ & $\begin{array}{c}\text { Long term } \\
\text { debt }\end{array}$ & $\begin{array}{c}\text { Growth } \\
\text { opportunities }\end{array}$ & Size & Age & $\begin{array}{c}\text { Non-debt } \\
\text { tax shields }\end{array}$ & $\begin{array}{c}\text { Profita- } \\
\text { bility }\end{array}$ & $\begin{array}{c}\text { Tangi- } \\
\text { bility }\end{array}$ \\
\hline Total debt & $\mathbf{1 . 0 0 0 0}$ & & & & & \\
\hline Long term debt & 0.6990 & $\mathbf{1 . 0 0 0 0}$ & & & & \\
\hline Growth opportunities & -0.1428 & -0.1479 & $\mathbf{0 . 7 5 0 0}$ & & & & \\
\hline Size & 0.1371 & 0.1615 & -0.0611 & $\mathbf{0 . 9 6 3 6}$ & & & \\
\hline Age & -0.1678 & -0.1312 & 0.0082 & -0.0378 & $\mathbf{1 . 0 0 0 0}$ & & \\
\hline Non-debt tax shields & -0.0913 & -0.0857 & 0.0108 & -0.1718 & -0.0096 & $\mathbf{0 . 7 4 1 1}$ & \\
\hline Profitability & -0.1779 & -0.0865 & 0.0520 & -0.0384 & 0.0547 & -0.0191 & $\mathbf{0 . 7 9 0 9}$ & \\
\hline Tangibility & 0.2079 & 0.1899 & -0.1242 & 0.1268 & -0.1441 & 0.1575 & -0.3166 & $\mathbf{0 . 9 6 7 3}$ \\
\hline
\end{tabular}

Note 1: The square root of AVE for each construct is presented on the diagonal and the remaining values correspond to the correlation between constructs.

Note 2: Constructs are defined in table 1.

Source: Authors.

As per Henseler, Ringle and Sarstedt (2015), the Heterotrait- of the measurement model, because the resulting values are Monotrait index test (HTMT) confirms the discriminant validity less than or equal to 0.6990 (Table 6).

\begin{tabular}{|l|l|l|l|l|l|l|l|}
\hline \multicolumn{1}{|c|}{ Constructs } & $\begin{array}{c}\text { Table 6 } \\
\text { Total } \\
\text { debt }\end{array}$ & $\begin{array}{c}\text { Long term } \\
\text { debt }\end{array}$ & $\begin{array}{c}\text { Growth } \\
\text { opportunities }\end{array}$ & Size & Age & $\begin{array}{c}\text { Non-debt tax } \\
\text { shields }\end{array}$ & Profitabi-lity \\
\hline Long term debt & 0.6990 & & & & \\
\hline $\begin{array}{l}\text { Growth } \\
\text { opportunities }\end{array}$ & 0.2922 & 0.2861 & & & & \\
\hline Size & 0.1336 & 0.1528 & 0.1116 & & & \\
\hline Age & 0.1678 & 0.1312 & 0.1078 & 0.0369 & & \\
\hline $\begin{array}{l}\text { Non-debt tax } \\
\text { shields }\end{array}$ & 0.2137 & 0.2010 & 0.4873 & 0.5254 & 0.0386 & \\
\hline Profitability & 0.1461 & 0.0897 & 0.2108 & 0.2875 & 0.0656 & 0.2744 & \\
\hline Tangibility & 0.2092 & 0.1961 & 0.2391 & 0.1103 & 0.1471 & 0.3879 & 0.3835 \\
\hline
\end{tabular}

Source: Authors.

In Table 7 and Figure 1 we present our results using the bootstrapping technique and with reference to 5000 samples. We also present the effects on endogenous variables and the tstatistics of structural model parameters, as well as the coefficients of determination $\left(R^{2}\right)$. In view of the explained variance values, the capital structure determinants hold different explanatory powers. Tangibility is the most relevant for both total indebtedness and long-term debt.

Table 7 - Effects on Endogenous Variables

\begin{tabular}{|c|c|c|c|}
\hline & Direct effect & t-value & Explained variance \\
\hline \multicolumn{4}{|c|}{ Dependent variable: Total debt (LEV) } \\
\hline H1 (-): GO $\rightarrow$ LEV & -0.1116 & $2.5890 * * *$ & $1.59 \%$ \\
\hline H2 (+): SIZE $\rightarrow$ LEV & 0.0851 & $1.7338^{*}$ & $1.17 \%$ \\
\hline H3 (-): AGE $\rightarrow$ LEV & -0.1377 & $2.6683 * * *$ & $2.31 \%$ \\
\hline H4 (-): NDTS $\rightarrow$ LEV & -0.1014 & $1.7332^{*}$ & $0.93 \%$ \\
\hline H5 (-): PROF $\rightarrow$ LEV & -0.1182 & $1.7730 *$ & $2.10 \%$ \\
\hline H6 (+): TANG $\rightarrow$ LEV & 0.1420 & $2.4369 * *$ & $2.95 \%$ \\
\hline \multicolumn{4}{|c|}{ Coefficient of determination $\mathrm{R}^{2}=\mathbf{0 . 1 1 0 5}$} \\
\hline \multicolumn{4}{|c|}{ Dependent variable: Long term debt (LLEV) } \\
\hline H1 (-): GO $\rightarrow$ LLEV & -0.1189 & $3.0266 * * *$ & $1.76 \%$ \\
\hline H2 (+): SIZE $\rightarrow$ LLEV & 0.1146 & $2.3003 * *$ & $1.85 \%$ \\
\hline H3 (-): AGE $\rightarrow$ LLEV & -0.1035 & $2.0066 * *$ & $1.36 \%$ \\
\hline H4 (-): NDTS $\rightarrow$ LLEV & -0.0902 & $1.7345 *$ & $0.77 \%$ \\
\hline H5 (-): PROF $\rightarrow$ LLEV & -0.0237 & 0.3934 & $0.21 \%$ \\
\hline H6 (+): TANG $\rightarrow$ LLEV & 0.1524 & $2.6192 * * *$ & $2.89 \%$ \\
\hline
\end{tabular}

Note 1: Note the significance level $(\alpha)$ and the $t$-value: ${ }^{*} t_{0.05 ; 4999}=|1.645|$ for $\alpha=10 \% ; * * t_{0.025 ; 4999}=|1.960|$ for $\alpha=5 \%$; $* * * t_{0.005 ; 4999}=|2.576|$ for $\alpha=1 \%$ Note 2: Constructs are defined in table 1. 


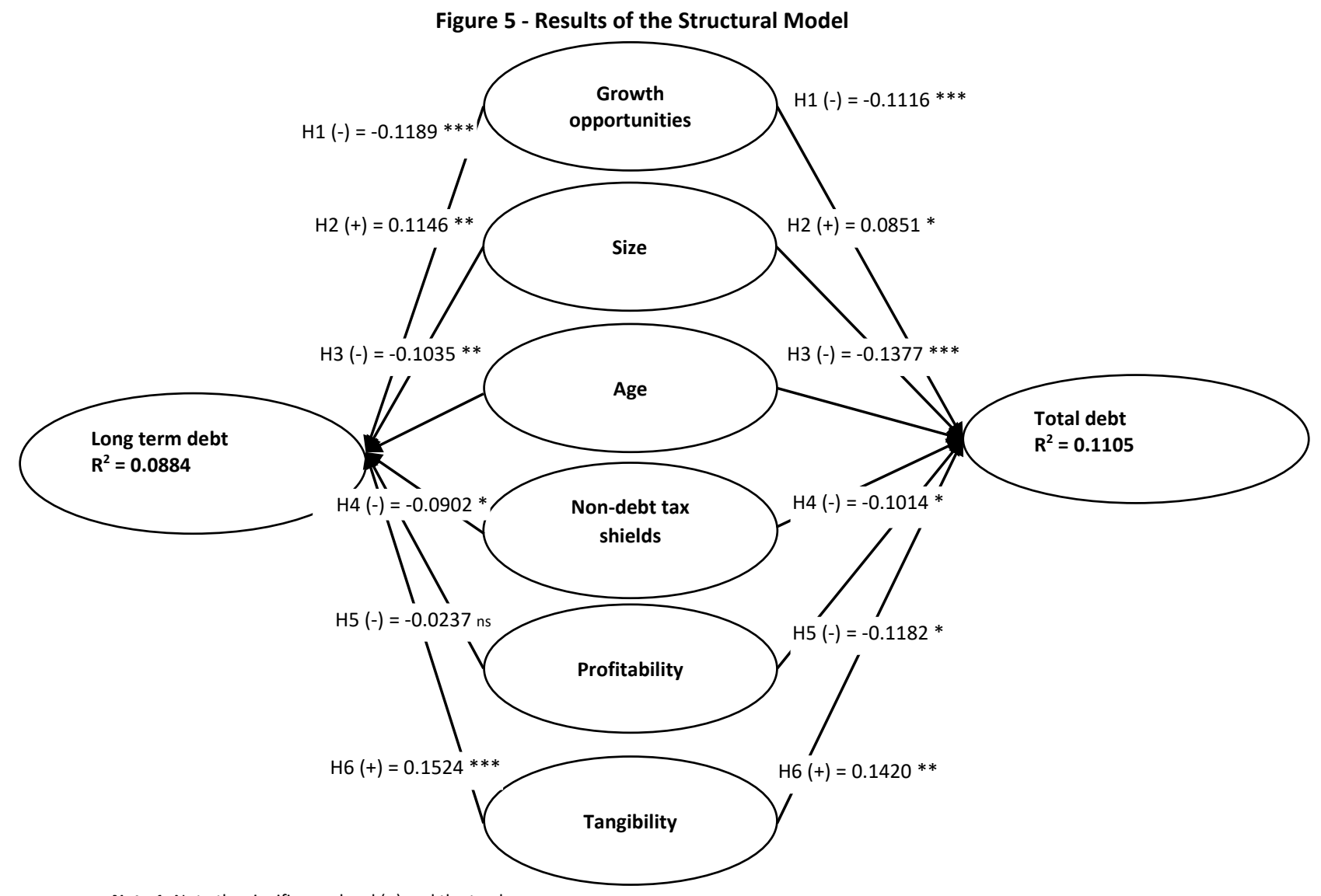

Note 1: Note the significance level $(\alpha)$ and the t-value:

$* \mathrm{t}_{0.05 ; 4999}=|1.645|$ for $\alpha=10 \%{ }^{* *} \mathrm{t}_{0.025 ; 4999}=|1.960|$ for $\alpha=5 \%{ }^{* * *} \mathrm{t}_{0.005 ; 4999}=|2.576| \quad$ for $\alpha=1 \%$ Note 2: Constructs are defined in table 1.

Source: Authors.

\subsection{Discussion of the results}

The results allow us to identify a negative relationship between future growth opportunities and debt for Portuguese hotel firms, so we do not reject hypothesis 1 . This result contradicts Dalbor and Upneja (2004) and Tang and Jang (2007), who also focused on the hotel industry and used market values in defining indicators, but it is in line with the results obtained by Serrasqueiro and Nunes (2014). Given the characteristics of the hotel business, capital intensive and seasonality, it is understandable that hotel firms with greater growth opportunities tend to reduce their indebtedness to avoid the associated financial risk, as established in the trade-off theory.

Size shows a positive and significant relationship with dependent variables, so we do not reject hypothesis 2 , although this independent variable has a weak explanatory power for total debt. The different levels of explanatory power on both dependent variables may possibly be associated with the fact that small firms are predominant in the sample. Those firms tend to borrow more in the short term than larger firms do (Titman \& Wessels, 1988), because the information asymmetry between stakeholders becomes particularly severe, given the poor quality of financial information (Lopez-Gracia \& AybarArias, 2000).
However, the result confirms the trade-off theory predictions that larger firms are less likely to go bankrupt because they can better enjoy the tax benefits of debt. This agrees with the empirical findings of Dalbor and Upneja (2004), Devesa and Esteban (2011) and Serrasqueiro and Nunes (2014).

There is a negative relationship between firm age and indebtedness, which supports the pecking-order theory. As predicted in hypothesis 3, which should not be rejected, Portuguese hotel firms with greater longevity tend to rely less on external funding. This is possibly because older firms have a higher self-funding potential and lower funding needs. The results corroborate those of Michaelas et al. (1999).

The non-debt tax shields variable correlates negatively with the indebtedness of Portuguese hotel firms, although its impact on dependent variables is low. As expected, the alternative tax benefit sources to interest, such as depreciation and amortization for the period, have a negative effect on manager's debt decision-making, so hypothesis 4 is not rejected. These results support the trade-off theory and are in line with those obtained by Serrasqueiro and Nunes (2014), which underscore the importance of this variable in explaining capital structure.

Profitability (past) of the Portuguese hotel industry has a negative relationship with indebtedness, but it does not 
correlate significantly with long-term debt and it has weak explanatory power for total debt. This means hypothesis 5 is not rejected as it pertains to total debt. Firms with higher profitability tend to be financed by internal funds, as predicted by pecking-order theory. Trade-off theory, on the other hand, tells us that larger firms will have greater borrowing capacity and will have higher indebtedness, so as to exploit the associated tax benefits. Matias and Baptista (1998) found a negative relationship with debt.

Finally, the tangibility variable is the most relevant in explaining the debt of the sample and has a positive effect. As a result, we do not reject the hypothesis 6 . Firms with more collateral value can more easily access credit, which helps them to minimise agency problems and asymmetric information. This supports both the trade-off and pecking-order theories and confirms the empirical findings of Dalbor and Upneja (2004), Tang and Jang (2007) and Serrasqueiro and Nunes (2014). Devesa and Esteban (2011) found empirical evidence in the opposite direction and claim that asset structure does not differentiate firms in the hotel sector, because the tangible assets have a high level of obsolescence that dictates frequent replacement.

\section{Conclusions}

This paper addresses the financial capital structure determinants of firms in the Portuguese hotel sector from a dynamic perspective (with the use of three sub-periods) and a structural equation model for 2006-2014 data from a sample of 356 companies.

Although the hotel industry is considered unique, because of its seasonality and capital intensiveness, our results do not differ from those found through empirical research into other sectors, with or without recourse to SEM methodology.

The results show that the explanatory variables proposed as capital structure determinants have an impact on indebtedness decisions and that tangibility has the greatest explanatory power of all. Tangibility and size relate directly to total and longterm debt ratios, while age, profitability (past), growth opportunities and non-debt tax shields have a reverse relationship.

Overall, the results imply that the trade-off and pecking-order theories are not mutually exclusive and that both of these are important in explaining the capital structure found in the Portuguese hotel industry, particularly as regards the agency conflicts arising from growth opportunities and the preference firms have for internal funding. The results also point to the importance of collateral value in accessing credit and the lower severity of asymmetric information associated with tangible asset value and firm size. In this context, the results suggest that small businesses have difficulties in contracting loans, which may possibly limit their growth and performance.

Given the importance of the hotel industry to Portugal, and the empirical evidence found here, we recommend decision makers pay attention to the conditions under which firms in this sector, especially SMEs, can access credit for the purposes of exploiting any investment opportunities that may arise.

This study also contains limitations. Due to lack of data, it does not include sector-specific variables to measure the specific financial determinants of the industry such, as the average revenue per room, occupancy rates and revenue per available room. Moreover, the relatively weak explanatory power of the model may suggest the need to include these variables.

We suggest that further research could focus on the use of SEM with such specific industry indicators as those mentioned above and better proxies for unobserved variables. It may also be important to investigate the behaviour of the financing decisions made by firms on the basis of debt maturity, including short-term debt, and by size category.

\section{References}

Ang, J. (1992). On the theory of finance for privately held firms. The Journal of Small Business Finance, 1(3), 185-203.

Chang, C., Lee, A., \& Lee, C. (2009). Determinants of capital structure choice: a structural equation modeling approach. The Quarterly Review of Economics and Finance, 49, 197-213.

Chen, S., \& Chen, L. (2011). Capital structure determinants: an empirical study in Taiwan. African Journal of Business Management, 5(27), 1097410983.

Chiarella, C., Pham, P., Sim, A., \& Tan, M. (1991). Determinants of capital structure: Australian evidence. University of Technology Sidney, Working Paper 3.

Cole, R. (2013). What do we know about the capital structure of privately held U.S. firms? Evidence from the surveys of small business finance. Financial Management, 45, 777-813.

Dalbor, M., \& Upneja A. (2004). The investment opportunity set and the long-term debt decision of U.S. lodging firms. Journal of Hospitability \& Tourism Research, 28(3), 346-355.

DeAngelo, H., \& Masulis, R. (1980). Optimal capital structure under corporate and personal taxation. Journal of Financial Economics, 8(1), 3-29.

Devesa, M., \& Esteban, L. (2011). Spanish hotel industry: indebtedness determinants. Applied Economics, 43, 4227-4238.

Fornell, C., \& Cha, J. (1994). Partial least squares. In Bagozzi, R.P. (eds.), Advanced Methods of Marketing Research, 52-789. Cambridge, MA: Blackwell Publishers.

Gefen, D., \& Straub, D. (2005). A practical guide to factorial validity using PLS-graph: Tutorial and annotated example. Communications of the Association for Information Systems, 16(1), 5.

Gefen, D., Straub, D. \& Rigdon, E. (2011). An update and extension to SEM guidelines for administrative and social science research. Management Information Systems Quarterly, 35(2), iii-xiv.

Graham, J., \& Harvey, C. (2001). The theory and practice of corporate finance: evidence from the field. Journal of Financial Economics, 60(2), 187-243.

Green, S. (1991). How many subjects does it take to do a regression analysis? Multivariate Behavioral Research, 26, 499 - 510.

Hall, G., Hutchinson, P., \& Michaelas, N. (2004). Determinants of the capital structures of European SMEs. Journal of Business Finance \& Accounting, 31(5-6), 711- 728.

Harris, M., \& Raviv, A. (1991). The theory of capital structure. The Journal of Finance, 46 (1), 297-355.

Henseler, J., Ringle, C., \& Sinkovics, R. R. (2009). The use of partial least squares path modeling in international marketing. Advances in International Marketing, 20, 277-319. 
Henseler, J., Ringle, C., \& Sarstedt, M. (2012). Using partial least squares path modeling in international advertising research: Basic concepts and recent issues. In Okzaki, S. (ed.). Handbook of partial least squares: Concepts, methods and applications in marketing and related field. Berlin: Springer.

Henseler, J., Ringle, C. M., \& Sarstedt, M. (2015). A New criterion for assessing discriminant validity in variance-based structural equation modeling. Journal of the Academy of Marketing Science, 43(1).

INE (2015). Estatísticas do Turismo 2014. Estatísticas Oficiais. 2015 edition.

Jairo, I. (2008). The use of structural equation modeling (SEM) in capital structure empirical analysis. KCA Journal of Business Management, 1(1).

López-Gracia, J., \& Aybar-Arias, C. (2000). An empirical approach to the financial behaviour of small and medium sized companies. Small Business Economics, 14(1), 55-63.

López-Gracia, J., \& Sogorb-Mira, F. (2008). Testing trade-off and pecking-order theories financing SMEs. Small Business Economics, 31(2), 117-136.

Matias, F., \& Baptista, C. (1998). Determinantes da estrutura de capital da indústria hoteleira algarvia - o caso dos hotéis", dos algarves, 3, 17-24.

Mateev, M., Poutziouris, P., \& Ivanov, K. (2013). On the determinants of SME capital structure in Central and Eastern Europe: a dynamic panel analysis. Research in International Business and Finance, 27, 28-51.

Michaelas, N., Chittenden, F., \& Poutziouris, P. (1999). Financial policy and capital structure choise in U.K. SMEs: Empirical evidence from company panel data. Small Business Economics, 12, 113-130.

Modigliani, F., \& Miller, M. H. (1958). The cost of capital, corporation finance and the theory of investment. The American Economic Review, 48(3), 261-297.

Modigliani, F., \& Miller, M. H. (1963). Corporate income taxes and the cost of capital: A correction. The American Economic Review, 53(3), 433-443.

Myers, S. (1984). The capital structure puzzle. The Journal of Finance, 39(3), 575- 592.

Myers, S., \& Majluf, N. (1984). Corporate financing and investment decisions when firms have information that investors do not have? Journal of Financial Economics, 13(2), 187-221.

Rajan, R., \& Zingales, L. (1995). What do we know about capital structure? Some evidence of international data. The Journal of Finance, 50(5), 1421-1460.

Ringle, C., Wende, S., \& Becker, J. (2015). SmartPLS 3. Bönningstedt: SmartPLS. Retrieved from http://www.smartpls.com.

Roldán, J., \& Sánchez-Franco, M. (2012). Variance-based structural equation modeling: Guidelines for using partial least squares in information systems research. In M. Moraet al. (Eds.) Research Methodologies in Engineering of Software Systems and Information Systems: Philosophies, Methods and Innovations, Chapter II.3. Hershey, PA: IGI Global.

Scott, J. (1976). A theory of optimal capital structure. The Bell Journal of Economics, 7(1), 33-54.

Serrasqueiro, Z., \& Nunes, P. M. (2014). Financing behaviour of Portuguese SMEs in hotel industry. International Journal of Hospitality Management, 43, 98-107.

Serrasqueiro, Z., \& Caetano, A. (2015). Trade-off theory versus pecking order theory: capital structure decisions in a peripheral region of Portugal. Journal of Business Economics and Management, 16(2), 445-466.

Tang, C. \& Jang, S. (2007). Revisit to the determinants of capital structure: A comparison between lodging firms and software firms. Hospitality Management, 26, 175-187.

Titman, S., \& Wessels, R. (1988). The determinants of capital structure choice. The Journal of Finance, 43(1), 1-19.

Webster, J., \& Watson, R. (2002). Analyzing the past to prepare for the future: Writing a literature review. MIS Quarterly, 26 (2), xiii-xxiii.
World Travel \& Tourism Council (WTTC, 2016). Travel \& Tourism Economy Impact 2016, Portugal. Retrieved from www.wttc.org/research/economic-research/economic-impactanalysis/country-reports.

Received: 20 February 2017

Revisions required: 25 July 2017

Accepted: 14 September 2017 